\title{
Association between MRI findings and back pain after osteoporotic vertebral fractures: a multicenter prospective cohort study
}

Sayed Abdullah Ahmadi, Shinji Takahashi, Masatoshi Hoshino, Kazushi Takayama, Ryuichi Sasaoka, Tadao Tsujio, Hiroyuki Yasuda, Fumiaki Kanematsu, Hiroshi Kono, Hiromitsu Toyoda, Hiroaki Nakamura

\begin{tabular}{|c|l|}
\hline Citation & The Spine Journal. 19(7); 1186-1193 \\
\hline Published & $2019-07$ \\
\hline Type & Journal Article \\
\hline Textversion & Author \\
\hline & $\begin{array}{l}\text { C } 2019 \text { Elsevier Inc. This manuscript version is made available under the } \\
\text { CC-BY-NC-ND 4.0 License. http://creativecommons.org/licenses/by-nc-nd/4.0/. } \\
\text { Rights }\end{array}$ \\
$\begin{array}{l}\text { This is the accepted manuscript version. The following manuscript has been } \\
\text { accepted by The Spine Journal. The final, published version is available at } \\
\text { https://doi.org/10.1016/j.spinee.2019.02.007. }\end{array}$ \\
\hline DOI & \begin{tabular}{l}
$10.1016 /$ j.spinee.2019.02.007 \\
\hline
\end{tabular} \\
\hline
\end{tabular}

\section{Self-Archiving by Author(s)}

Placed on: Osaka City University Repository

Sayed Abdullah Ahmadi, Shinji Takahashi, Masatoshi Hoshino, Kazushi Takayama, Ryuichi Sasaoka, Tadao Tsujio, Hiroyuki Yasuda, Fumiaki Kanematsu, Hiroshi Kono, Hiromitsu Toyoda, Hiroaki Nakamura. (2019). Association between MRI findings and back pain after osteoporotic vertebral fractures: a multicenter prospective cohort study. The Spine Journal. 19, 1186-1193. doi:

10.1016/j.spinee.2019.02.007 
Association between MRI findings and back pain after osteoporotic vertebral fractures: a multicenter prospective cohort study

Sayed Abdullah Ahmadi, MD a, Shinji Takahashi, MD. PhD. ${ }^{\text {a }}$, Masatoshi Hoshino, MD. PhD.

a, Kazushi Takayama, MD. PhD. ${ }^{\text {, }}$ Ryuichi Sasaoka, MD. PhD. ${ }^{\text {c }}$ Tadao Tsujio, MD. PhD. ${ }^{\text {, }}$ Hiroyuki Yasuda, MD. PhD. e, Fumiaki Kanematsu, MD. PhD. f , Hiroshi Kono, MD. PhD. ${ }^{\text {g }}$, Hiromitsu Toyoda, MD. PhD. ${ }^{\text {a }}$, Hiroaki Nakamura, MD. PhD. ${ }^{\text {a }}$

a Department of Orthopaedic Surgery, Osaka City University Graduate School of Medicine, Osaka, Japan

b Department of Orthopaedic Surgery, Seikeikai Hospital, Sakai, Osaka, Japan

c Department of Orthopaedic Surgery, Yodogawa Christian Hospital, Osaka, Japan

d Department of Orthopaedic Surgery, Shiraniwa Hospital, Ikoma, Nara, Japan

e Department of Orthopaedic Surgery, Osaka General Hospital of West Japan Railway

Company, Osaka, Japan

f Department of Orthopaedic Surgery, Saiseikai Nakatsu Hospital, Osaka, Japan

g Department of Orthopaedic Surgery, Ishikiri Seiki Hospital, Higashi Osaka, Osaka, Japan

*Corresponding author:

Shinji Takahishi MD, PhD.

Dept. of Orthopedic surgery, Osaka City University Graduate School of Medicine, Osaka, Japan

1-4-3, Asahimachi, Abenoku, Osaka city, Osaka, 545-8585, Japan 
E-mail: shinji@med.osaka-cu.ac.jp

TEL +81-6-6645-3851 FAX +81-6-6645-6260

Conflicts of Interest and Source of Funding:

The manuscript submitted does not contain information about medical device (s) /drug (s).

No funds were received in support of this work.

No relevant financial activities outside the submitted work.

\begin{abstract}
:
Background context: Osteoprotic vertebral fractures(OFV) are common in elderly people. The association between back pain due to OVF with MRI signal change is unclear. In this study we hypothesized that MRI findingswould be a predictive factor for back pain measured by VAS at 6 months follow-up.

Purpose: The aim was to study the magnetic resonance imaging (MRI) findings that predict back pain after osteoporotic vertebral fractures (OVF) and the association between radiological findings and scores of back pain .
\end{abstract}

Study design: Multicenter prospective cohort study.

Patient sample: A total of 153 OVF patients. 
Outcome measure: The outcome measures were VAS back pain and MRI signal change.

Methods: This study was performed from 2012 to 2015. Consecutive patients with less than 2-week old OVFs at 11 institutions were enrolled prospectively. MRI was performed at enrollment and at 1, 3 and 6 months follow-up. T1- and T2-weighted images (T1WI and T2W1) were obtained at each time point and their association with visual analogue scale (VAS) scores of back pain at 6 months were investigated. Anterior compression ratio, posterior compression ratio and angular motion of vertebral bodies were also measured on X-rays at each follow-up. Thisresearch had no financial support.There are no conflicts of interest.

Result: The 6 months follow-up was completed by 153 patients. At enrollment, the average VAS score of back pain was $75 \mathrm{~mm}$, and it had improved at the 6-month follow-up to an average score of $20 \mathrm{~mm}$. There was a significant correlation between T1 diffuse low signal change and VAS scores at the 6-month follow-up ( $\mathrm{p}<0.01)$. T2 high signal changes $(\mathrm{OR} ; 4.01, \mathrm{p}<0.01)$ and old vertebral fractures $(\mathrm{OR} ; 2.47$, $\mathrm{p}=0.04$ ) were independent risk factors for back pain. The correlation between angular motion of vertebrae on X-rays and the VAS score of back pain was significant at all time points.

\section{Conclusion:}

This study demonstrates the radiological factors associated with persistent back pain after an OVF and the association between the VAS score of back pain and radiological findings. In addition, T2 high signal changes in acute phase and old vertebral fractures were independent risk factors for residual back pain. 


\section{Introduction:}

Osteoporosis is a condition in which there is compromised bone strength due to deterioration in bone mass and quality.It is predominantly seen in the elderly, with 10 million individuals currently diagnosed with osteoporosis in the United States[1-4]. It is estimated that more than three times as many individuals have low bone mass and are at risk for the disease[5].Although the occurrence is often not recognized as a distinct clinical event, fractures can result in acute or chronic pain, height loss, spinal deformity (kyphosis, scoliosis), and restriction of thoracic and abdominal contents, impaired mobility and disability. Following conservative treatment, the pain associated with OVFs gradually decreasesdue to bony union and enhanced stability. However, some patients present with intractable back pain for extended periods of time. The causes of low back pain due to OVF are thus diverse, ranging from pain due to fractures in the acute phase and that caused by deformation of the spine from kyphosis in the chronic phase[6].

OVFs are evaluated by plain radiography and computed tomography.Management of the painin each phase (acute and chronic) depends on the radiographic findingsin the respective phases[7]. In OVF cases, insufficient union is often noted on plain radiography and/or MRI during follow-up[8].Plain radiography and computed tomographic changes are characterized by endplate deformities, loss of endplate parallelism, and a generally altered appearance compared with neighboring vertebrae in acute and chronic phase. $[9,10]$. In addition, radiographs taken in the sitting and standingposition can be used to assess the deformity andmobility of the fractured vertebrae[11,12]. However, an obvious deformity is not always observed at the time of injury[9], and the diagnosis is also difficult in patients with spinal abnormalities. Hence, MRI is now commonly performed to diagnose and confirm the age of OVFs[7]. MRI reveals the presence of pathological tissue conditions such as edema, hematoma and granulation, as well as the vascularity of the tissue[7,13], and is considered to provide valuable informationabout the OVF and its association with VAS score of back pain.However, there are only few reports about the correlation between VAS scores of back pain and radiological findings[14,15] 
This study was designed to evaluate the correlation between radiological findings from MRI and plain Xrays after an OVF and their ability to predict persistent pain 6 months after the OVF.

\section{Materials and methods}

A total of 153 consecutive patients with symptomatic OVFs were eligible for and willing to participate in this prospective multicenter cohort study, which was performed from January 2012 to September 2015. Eleven hospitals participated in this study. The inclusion criteria were age $>65$ years, diagnosis of an acuteOVF, and onset of back pain within 2 weeks prior to presentation. The exclusion criteria were pathological fractures, more than one acute fracture, malignant disease, dementia and high-energy injuries. Fractures were considered to be acute if the interval between the onset of symptoms and the first visit was $<2$ weeks and the MRI showed an abnormal signal change in the vertebral body. For evaluation of back pain VAS and MRI signal change, we used a classification based on our previous study[7,16].

\section{Clinical assessment}

The severity of pain was subjectively assessed by the patients on a visual analogue scale (VAS), which was based on the average level of back pain that the patient felt in the previous 1 week. The severity of pain on the VAS scale was reassessed at the time of enrollment and at the $1^{\text {st }}, 3^{\text {rd }}$, and $6^{\text {th }}$ month followups.We investigated patients' walking time per day (minutes) by a self-administered questionnaire.

\section{Imaging assessment}

At the time of enrollment and at the $1^{\text {st }}, 3^{\text {rd }}$, and $6^{\text {th }}$ month follow-ups, the patients were examined using plain X-rays and MRIs of the spine. Sagittal-view plain radiographs in both supine and weight-bearing 
positions were obtained. The relative height of the anterior wall (\%) of the affected vertebrawas calculated by the following formula: $[2 \times$ affected vertebral height/(lower vertebral height + upper vertebral height)] $\times 100$ (Fig. 1)[7]. When either the immediately cranial or caudal vertebral body was also deformed due to an old fracture, the vertical height of the anterior wall of the fractured vertebral body was divided by the vertical height of the anterior wall of the adjacent undeformed vertebral body.

Sagittal images of the spine, including the fractured vertebrae, were also obtained using 1.5- T MRI scanners in nine hospitals and 0.5-T scanners in two hospitals. The following sequences were obtained with 1.5-T MRI scanners: T1- weighted turbo spin echo with a slice thickness of 3mm (repetition time (TR) 400-700 ms and time to echo (TE) minimum accessible, depending on the capability of the machine) and the same sequence of T2-weighted images (TR 3000-4500 ms and TE 80-120ms). The following sequences were obtained with 0.5-T MRI scanners: T1-weighted turbo spin echo with a slice thickness of 3mm(TR 300-500 ms and TE 110-130 ms) and the same sequence with T2 (TR 3000-4000 ms and TE $110-130 \mathrm{~ms})$. The patterns of signal changes within fractured vertebral bodies on MRI were classified based on midsagittal and bilateral parasagittal T1WI and T2WI[7,16]. The signal changes on T1WI were classified into three patterns: diffuse low, confined low, and no signal change. The signal changes on T2WI were classified into four patterns: high, confined low, diffuse low, and no signal change. The weighted kappa showed excellent inter-rater and intra-rater agreement on both T1WI (0.844 and 0.907, respectively) and T2WI (0.712 and 0.731 , respectively)

\section{Statistical analysis}

One-way analyses of variance (ANOVA) were usedto test for significant between-group differences of VAS scores for eachof the MRI findings. Multivariate linear regression model adjusting for age, sex, old OVF, analgesic usageand walking time per day was used to assess the correlationbetween back pain and compression ratios/angular motion. Multivariate logistic regression analysis was used to assess the 
adjusted association of persistent back pain at $6^{\text {th }}$ months with MRI findings. The regression models were adjusted for age, sex, old OVF, analgesic usage and walking time per day.The odds ratio was considered significant at $\mathrm{p}<0.05$, odds ratios of factors at enrollment for back pain (VAS $>40)$ at 6-month follow-up. The receiver operatingcharacteristic (ROC) curve was used to investigatethe area under curve (AUC) of angular motion of the vertebra for persistent back pain. Statistical test results were considered significant at $\mathrm{p}<0.05$. All $\mathrm{p}$ values were two-sided. All analyses were performed using the SAS software package, version 9.4 (SAS Institute, Inc., Cary, NC).

Results

Of the 218 eligible patients, three died, eight were excluded because of another disease, and 54 were lost to follow up. Finally, 153 cases (125 females and 28 males) completed the 6-month follow up and were effectively analyzed. Their age at the time of enrollment ranged from 71 to 85 years, with a mean age of 78.5 years. Twenty-nine (18.9\%) OVFs were observed in the mid-thoracic spine (T7-T9), 99 (64.7\%) in the thoracolumbar spine (T10-L2) and $25(16.3 \%)$ in the lower lumbar spine (L3-L5)(Table 1). Overall, $47 \%$ of the patients were hospitalized for several weeks during the acute phase. During treatment, $30 \%$ of the patients wore tailor-made hard corsets, $62 \%$ wore tailor-made elastic corsets, $4 \%$ wore ready-made elastic corsets, and $4 \%$ did not wear a corset; mean duration of corset usage was 3.7 months $( \pm 2.7)$. The treatment for each patient was individualized by their respective physicians.

Severe back pain was reported by all the patientsat the time of study enrollment(average VAS score, 75 $\mathrm{mm}$ ), with pain intensity gradually improving thereafter until the 6-month follow-up (average VAS score at 6-months, $20 \mathrm{~mm}$ (Figure 2).

On T1-weighted MRI at 6-months follow-up,35.9\% of patients showed diffuse low changes, 53.6\% showed confined low changes, and $10.4 \%$ of patients showediso-intensity changes. There was a 
significant correlationbetween T1WI at the $6^{\text {th }}$ month follow-up and VAS scores of back pain $(\mathrm{p}<0.01)$ (Table 2).

On T2WI, all types of signal changes (diffuse low, confined low, iso-intensity and high signal changes) were seen at boththe patients' first visit and the 6-month follow-up. However, only the correlation between back pain VAS scores and T2WI changes at the $3^{\text {rd }}$ and $6^{\text {th }}$ month follow-up were significant $(\mathrm{p}=0.02 / \mathrm{p}<0.01)($ Table 3$)$.

Osteoporotic vertebral fracturesresulted in changes on the anterior and posterior sides and angular motion of thevertebra. As seen in Table 4,there was a significant correlation between anterior compression ratio and back pain VAS scores $(\mathrm{p}<0.01)$ at time of enrollment. Lower anterior compression ratio was associated with higher the back painat the time of enrollment and at the $1^{\text {st }}$ month follow$\mathrm{up}(\mathrm{p}<0.01 / \mathrm{p}=0.02)$. Greater angular motion correlated significantly with higher back pain VAS scores at all time points (Table 4).

Table 5shows the results ofmultiplelogistic regression analyses, which revealed that T2 high signal changes $(\mathrm{OR} ; 3.96, \mathrm{p}<0.01)$ and old vertebral fracture $(\mathrm{OR} ; 2.43, \mathrm{p}=0.04)$ were independent risk factors for back pain at the 6-month follow-up (Table5).Area under curve (AUC) of vertebral angular motion for persistent back pain at 6-month follow-up was $0.571(\mathrm{p}=0.244)$.

\section{Discussion}

This study demonstrated the association between radiological findings and VAS scores of back pain according to the age of the OVF. We alsoinvestigatedpredictive radiological findings in patients with back pain.Osteoporotic vertebral fracturesmay be accompanied by severe acute pain in some cases, and by almost no pain in some mild cases, depending on the severity of vertebral body collapse. In the present study, the severity of back pain at the time of enrollment was a VAS score of $75 \mathrm{~mm}$, and it gradually 
improved by the6-months follow-up. However, some amount of residual pain still remained at the6monthfollow-up (VAS=25mm).

MRI allows imaging in several planes.Accurate delineation of a compression fracture can be confirmed by the presence or absence of signal change and the altered radiological features. Furthermore, MRI can differentiate between new and old fractures and degenerative lesions. Hence, we used MRI as the imaging modality in the current study. Several approaches have been used to classify MRI findings of OVFs[7,14,16-18].Chou et al. showed the healing process of OVFs using temporal MRIs. They used eight categories of MRI findings and concluded that there was no association between MRI findings and back pain[17]. However, they analyzed only a small sample of 32 patients and did not evaluate the reliability of their MRI classification of OVFs. Although the Denis classification is sometimes used for OVFs, it is not sufficiently reproducible for comparison of different patient series[19]. In this study, we used a simple MRI classification[7]to consider back pain according to the age of the OVF.

There are no previous data regarding the association between MRI signal changesand VAS scores of back pain.Signal changes in the vertebral body on MRI may also represent hematoma and inflammation adjacent to the disrupted trabeculae and cortex in the acute or subacute phase of OVFs[18,20,21].Areas of low signal changes might be related to bone damage, such as bone bruising or trabecular fracture.Meyers et al described fractures as having intramedullary lines of very low signal intensity extending to the intercortical margin on T1WI[22]. These lines are frequently surrounded by larger irregular zones of marrow abnormalities, characterized by a slightly decreased signal intensity on T1WI and cortex in the acute or subacute phase[19-21]. According to the Takahashi classification[7] (Figure3) used in our study,diffuse low intensity signal changes were seen at the time of enrollment and at the 1-, 3- and 6month follow-ups. They reported that the frequency of diffuse low signal changes on T2WI were much lower than those on T1WI at enrollment and at the $1^{\text {st }}$ month follow-up[23].In this study as well,we found a much higher incidence of diffuse low signal changes on T1MRI than onT2MRIat enrollment and the $1^{\text {st }}$ month follow-up. High signal changes on T2-weighted MRI reportedly have a high sensitivity and 
specificityfor predicting delayed union at all time points[16]. Therefore, in the current study, we investigatedthe correlation between T2-weighted MRI signal changesafter OVF and the VAS scores of back pain. We found diffuse low, confined low, iso-intensity, and high intensity signal changes on T2 MRI in all our patients at enrollment, and at the $1^{\text {st }}, 3^{\text {rd }}$, and $6^{\text {th }}$ month follow-ups. However, the correlation between T2 MRI signal changes and VAS scores of back pain were significant at only the $3^{\text {rd }}$ and $6^{\text {th }}$ monthfollow-up. Also, T2 high signal changes at the time of injury was a predictive factor for residual back pain at the $6^{\text {th }}$ month follow-up. However, the incidenceof diffuse low signal changes on T1 MRI was higher than that of diffuse low signal changes onT2WIat the $6^{\text {th }}$ month follow-up on back pain VAS scores, which implies that T1 diffuse low signal changes may represent bone edema rather than a trabecular fracture. In the current study, we also found on T1WI that diffuse low signal changes were seen in patients with a high back pain VAS score at all time points.

In the current study, X-rays demonstrated that anterior compression ratio, posterior compression ratio, and angular motion were different between enrollment and at the $1^{\text {st }}, 3^{\text {rd }}$, and $6^{\text {th }}$ month follow ups. In addition, the presence of ongoing angular motion of the fractured vertebra resulted in nonunion after the OVF[13]. These findings suggest that it is important to check for angular motionusing weight bearing (supine vs upright)X-rays in patients with persistent severe back pain after acute OVF and at the $6^{\text {th }}$ month follow-up.Traditionally, radiographic imaging is the first step in the evaluation of painful spinal disorders. In the present study, anterior compression ratio, posterior compression ratio and angular motion had a significant correlation with back pain VAS scores in the acute phase. In the acute phase, deformity of the vertebral body is not obvious on $\mathrm{X}$ rays in some cases. Dull myofascial pain may persist throughout the paraspinal region secondary to sustained positive balance even after the acute pain has subsided.Fora few months after the occurrence of pain, deformation of the vertebral body tends to accelerate and there is a significant correlation of the posterior compression ratio and angular motion with back pain VAS scores atthe $1^{\text {st }}$ month follow-up. Anterior compression angle were changed from acute phase $11.2 \mathrm{~mm}$ to 14.4mm in 6 months follow-up. Dynamic(flexion vs extension) X-rays are also particularly important in 
the diagnosis of intravertebral clefts[24,25]. Further, segmental angular motion is important in terms of the association between back pain and neurological deficits[8]. In our series, angular motion correlated significantlywith back pain VAS scores at all the follow-up time points (at enrollment, $1^{\text {st }}, 3^{\text {rd }}$, and $6^{\text {th }}$ months).

\section{Limitations:}

This study has several limitations. First, the current study compared MRI and X-ray findings with VAS scores of back pain in Japanese subjects, and hence, the results might not be generalizable to all populations. Second, 65 of our patients were lost to follow-up for unknownreasons. A potential reason for this could be that patients whose symptoms improved were unlikely to visit the hospital. We evaluated the VAS of back pain, levels of fractures, height and age of patients between the patients who lost follow-up and who completed 6 months follow-up and there was no significant differences between groups. Third, this study used different MRI scanners with different technicians in different institutions.In nine of the hospitals, the MRIswereof the same quality, and in two hospitals they were of different quality. Fourth, we used a simpleMRI classification of OVFs in this study. However,the results showed high reliability and the weighted kappa showed excellent inter-rater and intra-rater agreement on both T1WI (0.844 and 0.907, respectively) and T2WI (0.712 and 0.731, respectively)[7]. Finally, we could not evaluate the degree of back pain before the fracture and its influence on the results of this study.

Conclusion:

The present study demonstrated the radiologicalfactors associated withback pain after an OVFand investigatedthe associationbetweenVAS scores of back pain and the radiological findings (MRI and plain $\mathrm{X}$-rays). The presence of $\mathrm{T} 2$ high signal changes at $3^{\text {rd }}$ and $6^{\text {th }}$ months follow-upwasrelated to current back pain.X-ray evaluation showed that angular motion was changed at all follow-up time points and there was a significant correlation between angular motion and VAS scores of back pain at all time points.In 
addition, T2 high signal changes in acute phase and old vertebral fractures were independent risk factors for residual back pain. Surgical interventionor other conservative treatments should be consideredin these cases. 
References:

[1] Bessette L, Ste-Marie L-G, Jean S, Shawn Davison K, Beaulieu M, Baranci M, et al. Recognizing osteoporosis and its consequences in Quebec (ROCQ): Background, rationale, and methods of an anti-fracture patient health-management programme. Contemp Clin Trials 2008;29:194-210.

[2] Mears SC, Kates SL. A Guide to Improving the Care of Patients with Fragility Fractures, Edition 2. Geriatr Orthop Surg Rehabil.2015;6:58-120.

[3] Varacallo MA, Fox EJ, Paul EM, Hassenbein SE, Warlow PM. Patients' response toward an automated orthopedic osteoporosis intervention program. Geriatr Orthop Surg Rehabil 2013;4:8998.

[4] Diab DL, Watts NB. Diagnosis and Treatment of Osteoporosis in Older Adults. Endocrinol Metab Clin North Am2013;42:305-17.

[5] Friedlaender GE. The role of the orthopaedic surgeon in minimizing mortality and morbidity associated with fragility fractures. J Am Acad Orthop Surg 2010;18:515.

[6] Toshitaka NAKAMURA. Low Back Pain Accompanying Osteoporosis. Japan Med Assoc 2003;10:46.

[7] Takahashi S, Hoshino M, Takayama K, Iseki K, Sasaoka R, Tsujio T, et al. Time course of osteoporotic vertebral fractures by magnetic resonance imaging using a simple classification: a multicenter prospective cohort study. Osteoporos Int 2016;28:473-82. 3737-x.

[8] Hoshino M, Nakamura H, Terai H, Tsujio T, Nabeta M, Namikawa T, et al. Factors affecting neurological deficits and intractable back pain in patients with insufficient bone union following osteoporotic vertebral fracture. Eur Spine J 2009;18:1279-86.

[9] Krege JH, Siminoski K, Adachi JD, Misurski DA, Chen P. A simple method for determining the 
probability a new vertebral fracture is present in postmenopausal women with osteoporosis. Osteoporos In 2006; 17:379-86.

[10] Lenchik L, Rogers LF, Delmas PD, Genant HK. Diagnosis of Osteoporotic Vertebral Fractures: Importance of Recognition and Description by Radiologists. AJR Am J Roentgenol 2004;183:949-58.

[11] Toyone T, Toyone T, Tanaka T, Wada Y, Kamikawa K, Ito M, et al. Changes in Vertebral Wedging Rate Between Supine and Standing Position and its Association With Back Pain: A Prospective Study in Patients With Osteoporotic Vertebral Compression Fractures. Spine 2006;31:2963-6.

[12] Fang X, Yu F, Fu S, Song H. Intravertebral clefts in osteoporotic compression fractures of the spine: Incidence, characteristics, and therapeutic efficacy. Int J Clin Exp Med2015;8:16960-8.

[13] Toyoda H, Takahashi S, Hoshino M, Takayama K, Iseki K, Sasaoka R, et al. Characterizing the course of back pain after osteoporotic vertebral fracture: a hierarchical cluster analysis of a prospective cohort study. Arch Osteoporos 2017;12:82.

[14] Clark EM, Cummings SR, Schousboe JT. Spinal radiographs in those with back pain —when are they appropriate to diagnose vertebral fractures? Osteoporos Int 2017:2293-7.

[15] Black DM, Cummings SR, Karpf DB, Cauley JA, Thompson DE, Nevitt MC, et al. Randomised trial of effect of alendronate on risk of fracture in women with existing vertebral fractures. Fracture Intervention Trial Research Group. Lancet 1996;348:1535-41.

[16] Tsujio T, Nakamura H, Terai H, Hoshino M, Namikawa T, Matsumura A, et al. Characteristic radiographic or magnetic resonance images of fresh osteoporotic vertebral fractures predicting potential risk for nonunion: A prospective multicenter study. Spine 2011;36:1229-35. 
[17] Cho T, Matsuda M, Sakurai M. MRI findings on healing process of vertebral fracture in osteoporosis. J Orthop Sci 1996;1:16-33.

[18] Kanchiku T, Taguchi T, Kawai S. Magnetic resonance imaging diagnosis and new classification of the osteoporotic vertebral fracture. J Orthop Sci 2003;8:463-6.

[19] Oner FC, Ramos LM, Simmermacher RK, Kingma PT, Diekerhof CH, Dhert WJ, et al. Classification of thoracic and lumbar spine fractures: problems of reproducibilityA study of 53 patients using CT and MRI. Eur Spine J 2002;11:235-45.

[20] Smith SR, Williams CE, Davies JM, Edwards RH. Bone marrow disorders: characterization with quantitative MR imaging. Radiology 1989;172:805-10.

[21] Vogler JB, Murphy WA. Bone marrow imaging. Radiology 1988;168:679-93.

[22] Meyers SP, Wiener SN. Magnetic resonance imaging features of fractures using the short tau inversion recovery (STIR) sequence: correlation with radiographic findings. Skeletal Radiol1991;20:499-507.

[23] Takahashi S, Hoshino M, Takayama K, Iseki K, Sasaoka R, Tsujio T, et al. Predicting delayed union in osteoporotic vertebral fractures with consecutive magnetic resonance imaging in the acute phase: a multicenter cohort study. Osteoporos Int 2016;27:3567-75.

[24] Hasegawa K, Homma T, Uchiyama S, Takahashi H. Vertebral pseudarthrosis in the osteoporotic spine. Spine 1998;23:2201-6.

[25] McKiernan F, Jensen R, Faciszewski T. The dynamic mobility of vertebral compression fractures. J Bone Miner Res 2003;18:24-9. 
Tables

Table1: Patients demographicdata

Table 2: Correlation between findings on T1WI andVAS scores of back pain

Table 3: Correlation between findings on T2WI and VAS scores of back pain

Table 4: Correlation between back pain and compression ratios/angular motion

Table 5: Odds ratios of factors at enrollment that were associated with back pain (VAS >40) at the 6month follow-up. 
Table 1 Patients demographic data

\begin{tabular}{lll}
\hline Parameters & Levels & $\begin{array}{l}\text { Mean (SD) } \\
\text { or (\%) }\end{array}$ \\
\hline Age & & $78.5 \pm 7.1$ \\
$\begin{array}{l}\text { Sex } \\
\text { Male }\end{array}$ & & $28(18.3 \%)$ \\
$\begin{array}{l}\text { Female } \\
\text { OVF levels }\end{array}$ & T7-T9 & $\mathrm{N}=29(18.9 \%)$ \\
$\begin{array}{l}\text { Mid-thoracic } \\
\text { spine }\end{array}$ & The \\
$\begin{array}{l}\text { Thoracolumbar } \\
\text { spine }\end{array}$ & T10-L2 & $\mathrm{N}=99(64.7 \%)$ \\
$\begin{array}{l}\text { Lower lumbar } \\
\text { spine }\end{array}$ & L3-L5 \\
$\begin{array}{l}\text { Old fracture } \\
\text { Analgesic } \\
\text { usage }\end{array}$ & & $\mathrm{N}=25(16.3 \%)$ \\
\hline
\end{tabular}


Table 2 Correlation between findings on T1WI and VAS scores of back pain

\begin{tabular}{|c|c|c|c|c|}
\hline Parameters & $\begin{array}{l}\text { Number } \\
\text { of } \\
\text { patients }\end{array}$ & VAS score & $\begin{array}{l}\text { Mean + SD } \\
\text { of VAS } \\
\text { score }\end{array}$ & $\mathrm{P}$ value \\
\hline \multicolumn{5}{|l|}{ T1 changes at first visit } \\
\hline Diffuse low signal change on MRI & 66 & $\begin{array}{l}\text { VAS at first } \\
\text { visit }\end{array}$ & $74.6 \pm 15.9$ & 0.16 \\
\hline $\begin{array}{l}\text { Confined low signal change on } \\
\text { MRI }\end{array}$ & 87 & $\begin{array}{l}\text { VAS at first } \\
\text { visit }\end{array}$ & $69.9 \pm 22.8$ & \\
\hline Iso-intensity change on MRI & 0 & & & \\
\hline $\begin{array}{l}\text { T1 changes at } 1^{\text {st }} \text { month follow up } \\
\text { Diffuse low signal change on MRI }\end{array}$ & $131 / 147$ & $\begin{array}{l}\text { VAS at } 1^{\text {st }} \\
\text { month }\end{array}$ & $38.6 \pm 23.5$ & 0.87 \\
\hline $\begin{array}{l}\text { Confined low signal change on } \\
\text { MRI }\end{array}$ & $16 / 147$ & $\begin{array}{l}\text { VAS at } 1^{\text {st }} \\
\text { month }\end{array}$ & $37.6 \pm 27.2$ & \\
\hline Iso-intensity change on MRI & 0 & & & \\
\hline \multicolumn{5}{|l|}{ T1 changes at $3^{\text {rd }}$ month follow up } \\
\hline Diffuse low signal change on MRI & $83 / 138$ & $\begin{array}{l}\text { VAS at } 3^{\text {rd }} \\
\text { month }\end{array}$ & $28.3 \pm 25.7$ & 0.66 \\
\hline $\begin{array}{l}\text { Confined low signal change on } \\
\text { MRI }\end{array}$ & $50 / 138$ & $\begin{array}{l}\text { VAS at } 3^{\text {rd }} \\
\text { month }\end{array}$ & $26.1 \pm 22.7$ & \\
\hline Iso-intensity change on MRI & $5 / 138$ & $\begin{array}{l}\text { VAS at } 3^{\text {rd }} \\
\text { month }\end{array}$ & $18.8 \pm 27.4$ & \\
\hline \multicolumn{5}{|l|}{ T1 changes at $6^{\text {th }}$ month follow up } \\
\hline Diffuse low signal change on MRI & 55 & $\begin{array}{l}\text { VAS at } 6^{\text {th }} \\
\text { month }\end{array}$ & $30.5 \pm 27.7$ & $<0.01$ \\
\hline $\begin{array}{l}\text { Confined low signal change on } \\
\text { MRI }\end{array}$ & 82 & $\begin{array}{l}\text { VAS at } 6^{\text {th }} \\
\text { month }\end{array}$ & $17.9 \pm 22.6$ & \\
\hline Iso-intensity change on MRI & 16 & $\begin{array}{l}\text { VAS at } 6^{\text {th }} \\
\text { month }\end{array}$ & $12.6 \pm 19.7$ & \\
\hline
\end{tabular}


Table 3 Correlation between T2WI and VAS scores of back pain

\begin{tabular}{|c|c|c|c|c|}
\hline Parameters & $\begin{array}{l}\text { Number } \\
\text { of } \\
\text { patients }\end{array}$ & VAS score & $\begin{array}{l}\text { Mean + SD of } \\
\text { VAS score }\end{array}$ & $\mathrm{P}$ value \\
\hline \multicolumn{5}{|l|}{ T2 changes at first visit } \\
\hline $\begin{array}{l}\text { Diffuse low signal change on } \\
\text { MRI }\end{array}$ & 10 & $\begin{array}{l}\text { VAS at first } \\
\text { visit }\end{array}$ & $67.9 \pm 19.7$ & 0.83 \\
\hline $\begin{array}{l}\text { Confined low signal change on } \\
\text { MRI }\end{array}$ & 90 & $\begin{array}{l}\text { VAS at first } \\
\text { visit }\end{array}$ & $71.3 \pm 21.0$ & \\
\hline Iso-intensity change on MRI & 22 & $\begin{array}{l}\text { VAS at first } \\
\text { visit }\end{array}$ & $73.0 \pm 17.2$ & \\
\hline High signal change on MRI & 31 & $\begin{array}{l}\text { VAS at first } \\
\text { visit }\end{array}$ & $74.0 \pm 20.9$ & \\
\hline \multicolumn{5}{|l|}{ T2 changes at $1^{\text {st }}$ month follow up } \\
\hline $\begin{array}{l}\text { Diffuse low signal change on } \\
\text { MRI }\end{array}$ & 24 & $\begin{array}{l}\text { VAS at } 1^{\text {st }} \\
\text { month }\end{array}$ & $40.1 \pm 24.9$ & 0.83 \\
\hline $\begin{array}{l}\text { Confined low signal change on } \\
\text { MRI }\end{array}$ & 81 & $\begin{array}{l}\text { VAS at } 1^{\text {st }} \\
\text { month }\end{array}$ & $36.9 \pm 23.0$ & \\
\hline Iso-intensity change on MRI & 5 & $\begin{array}{l}\text { VAS at } 1^{\text {st }} \\
\text { month }\end{array}$ & $45.0 \pm 22.0$ & \\
\hline High signal change on MRI & 37 & $\begin{array}{l}\text { VAS at } 1^{\text {st }} \\
\text { month }\end{array}$ & $40.0 \pm 25.8$ & \\
\hline \multicolumn{5}{|l|}{$\mathrm{T} 2$ changes at $3^{\text {rd }}$ month follow up } \\
\hline $\begin{array}{l}\text { Diffuse low signal change on } \\
\text { MRI }\end{array}$ & 14 & $\begin{array}{l}\text { VAS at } 3^{\text {rd }} \\
\text { month }\end{array}$ & $26.5 \pm 22.9$ & 0.02 \\
\hline $\begin{array}{l}\text { Confined low signal change on } \\
\text { MRI }\end{array}$ & 78 & $\begin{array}{l}\text { VAS at } 3^{\text {rd }} \\
\text { month }\end{array}$ & $24.2 \pm 23.3$ & \\
\hline Iso-intensity change on MRI & 15 & $\begin{array}{l}\text { VAS at } 3^{\text {rd }} \\
\text { month }\end{array}$ & $19.9 \pm 19.0$ & \\
\hline High signal change on MRI & 31 & $\begin{array}{l}\text { VAS at } 3^{\text {rd }} \\
\text { month }\end{array}$ & $39.5 \pm 28.5$ & \\
\hline \multicolumn{5}{|l|}{$\mathrm{T} 2$ changes at $6^{\text {th }}$ month follow up } \\
\hline $\begin{array}{l}\text { Diffuse low signal change on } \\
\text { MRI }\end{array}$ & 7 & $\begin{array}{l}\text { VAS at } 6^{\text {th }} \\
\text { month }\end{array}$ & $26.1 \pm 25.1$ & $<0.01$ \\
\hline $\begin{array}{l}\text { Confined low signal change on } \\
\text { MRI }\end{array}$ & 80 & $\begin{array}{l}\text { VAS at } 6^{\text {th }} \\
\text { month }\end{array}$ & $21.1 \pm 23.2$ & \\
\hline Iso-intensity change on MRI & 40 & $\begin{array}{l}\text { VAS at } 6^{\text {th }} \\
\text { month }\end{array}$ & $13.8 \pm 21.4$ & \\
\hline High signal change on MRI & 26 & $\begin{array}{l}\text { VAS at } 6^{\text {th }} \\
\text { month }\end{array}$ & $35.6 \pm 30.5$ & \\
\hline
\end{tabular}


Table 4 Correlation between back pain and compression ratios/angular motion

\begin{tabular}{cllllll}
\hline & \multicolumn{2}{l}{$\begin{array}{l}\text { Anterior compression } \\
\text { ratio }\end{array}$} & \multicolumn{2}{l}{$\begin{array}{l}\text { Posterior compression } \\
\text { ratio }\end{array}$} & \multicolumn{2}{l}{ Angular motion } \\
\hline & $\beta$ & P-value & $\beta$ & P-value & $\beta$ & P-value \\
\hline At injury & 0.77 & $<0.01$ & 0.82 & $<0.01$ & 1.12 & 0.11 \\
$1^{\text {st }}$ month & 0.14 & 0.25 & 0.33 & 0.03 & 1.13 & 0.06 \\
$3^{\text {rd }}$ month & 0.22 & 0.08 & 0.27 & 0.08 & 1.77 & $<0.01$ \\
$6^{\text {th }}$ month & 0.11 & 0.12 & 0.21 & 0.11 & 2.02 & $<0.01$ \\
\hline
\end{tabular}

The multiple linear regression model was adjusted for age, sex, old OVF, analgesic usage and walking time per day (minutes). 
Table 5 Odds ratios of factors at enrollment related to back pain (VAS $>40 \mathrm{~mm}$ ) at the 6-month follow-up

\begin{tabular}{|c|c|c|c|c|}
\hline Parameters & Odds ratio & $95 \% \mathrm{CI}$ & & P-value \\
\hline Age $65-75 y$ & ref & & & \\
\hline Age $>75 y$ & 1.98 & 0.34 & 11.44 & 0.45 \\
\hline Age $>85 y$ & 1.44 & 0.26 & 8.05 & 0.68 \\
\hline Sex ( Male) & 0.71 & 0.22 & 2.28 & 0.56 \\
\hline $\begin{array}{l}\text { T1 confined low or } \\
\text { iso-intensity }\end{array}$ & ref & & & \\
\hline $\begin{array}{l}\text { T1 diffuse low } \\
\text { signal }\end{array}$ & 1.06 & 0.43 & 2.63 & 0.90 \\
\hline $\begin{array}{l}\text { T2 confined low or } \\
\text { iso-intensity }\end{array}$ & ref & & & \\
\hline T2 high signal & 3.96 & 1.50 & 10.48 & 0.01 \\
\hline $\begin{array}{l}\text { T2 diffuse low } \\
\text { signal }\end{array}$ & 2.56 & 0.54 & 12.03 & 0.24 \\
\hline Thoracic spine & ref & & & \\
\hline $\begin{array}{l}\text { Thoracolumbar } \\
\text { spine }\end{array}$ & 0.68 & 0.20 & 2.30 & 0.53 \\
\hline Lumbar spine & 1.24 & 0.30 & 5.10 & 0.76 \\
\hline $\begin{array}{l}\text { Posterior wall injury } \\
\text { (present) }\end{array}$ & 2.31 & 0.91 & 5.82 & 0.08 \\
\hline Old OVF (present) & 2.43 & 1.01 & 5.89 & 0.04 \\
\hline $\begin{array}{l}\text { Walking time per } \\
\text { day (per minute). }\end{array}$ & 1.00 & 0.98 & 1.01 & 0.45 \\
\hline
\end{tabular}


Figures:

Figure 1: X-rays of the spine showing osteoporotic vertebral fractures (OVFs) a) The percentage height of the anterior wall was calculated by the formula: $[2 a /(b+c)] * 100 . b)$ Vertebral segmental angle in the supine position, 'a' degrees. c)Vertebral segmental angle in the weight bearing position, 'b' degrees

Figure 1. (a)

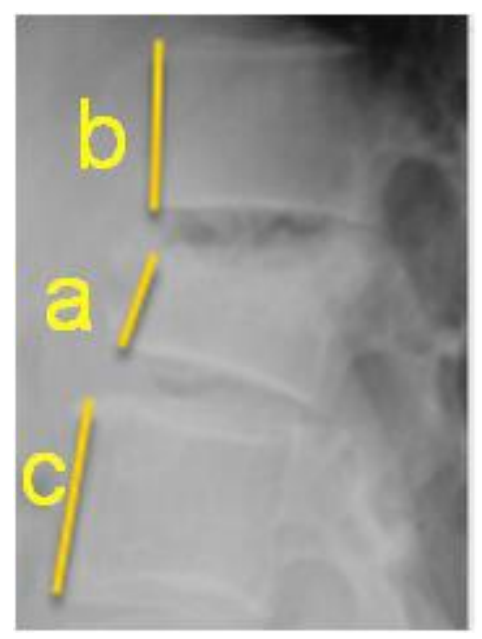

Figure 1. (b)

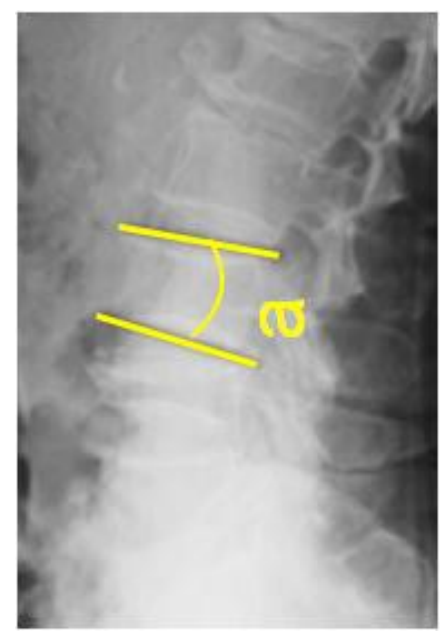

Figure 1. (c)

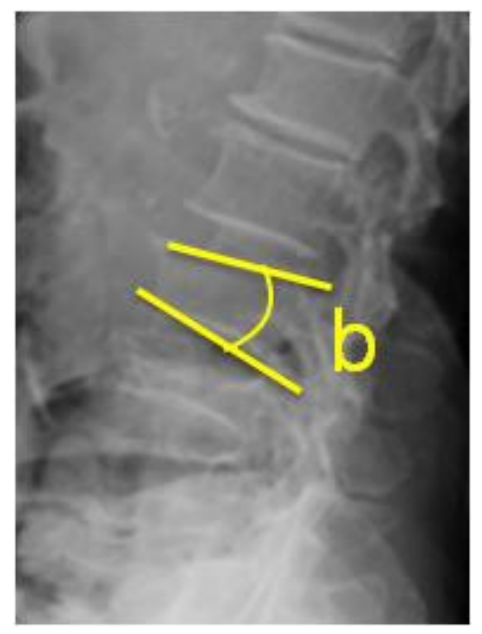


Figure 2: VAS scores of back pain

Figure 2.

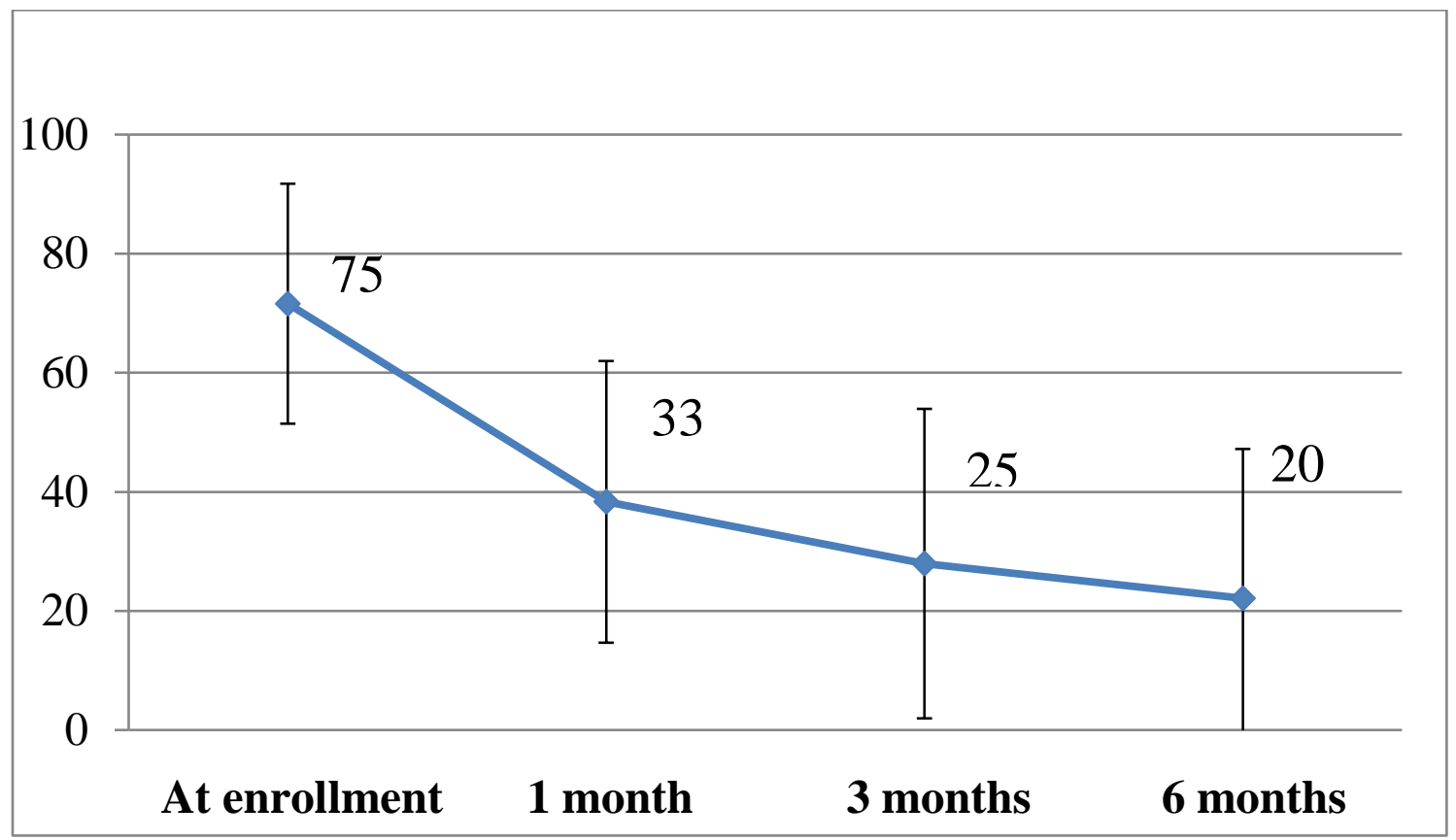


Figure 3: MRI findings:Asimple classification of OVF

Figure 3. (a)
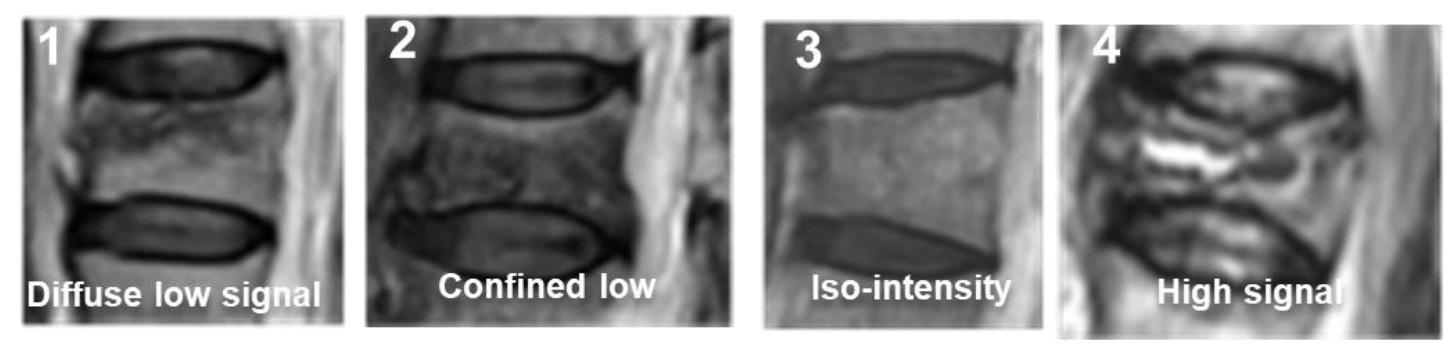

Figure 3. (b)
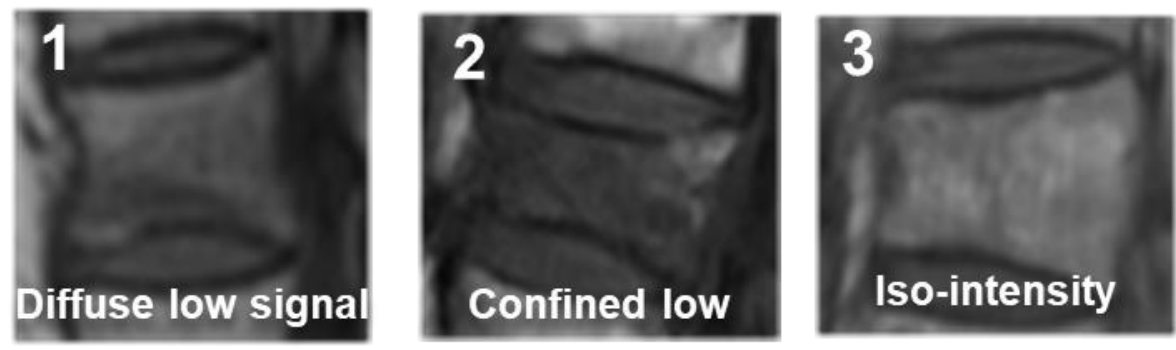
Figure 4: Area under curve (AUC) of vertebral angularmotion for persistent back pain at 6-month followup is 0.571 .

\section{Figure 4.}

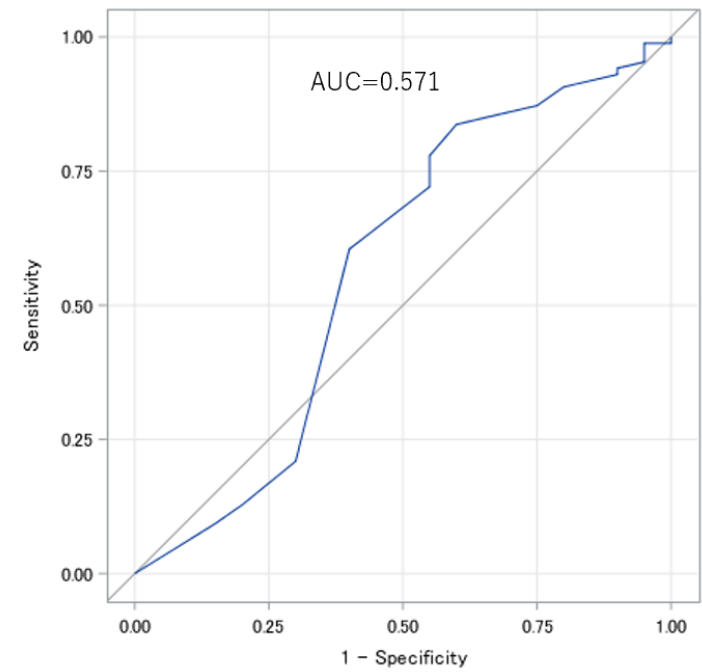

